\title{
Implementation of IFRS as Indian Accounting Standard for Similarity in Financial Reporting in India: Challenges \& Benefits
}

\author{
Ram Singh $^{1}$, Santosh Kumar Srivastava ${ }^{2}$ \\ ${ }^{1}$ School of Business \& Management, Quantum University, Roorkee, India \\ ${ }^{2}$ School of Commerce, HNB Garhwal Central University, Garhwal, India
}

Email address:

ramsinghcommerce gmail.com (R. Singh), dr.santosh.srivastava@gmail.com (S. K. Srivastava)

To cite this article:

Ram Singh, Santosh Kumar Srivastava. Implementation of IFRS as Indian Accounting Standard for Similarity in Financial Reporting in India: Challenges \& Benefits. American Journal of Theoretical and Applied Business. Vol. 5, No. 4, 2019, pp. 90-96.

doi: 10.11648/j.ajtab.20190504.12

Received: September 3, 2019; Accepted: September 30, 2019; Published: October 17, 2019

\begin{abstract}
International Financial Reporting Standards (IFRS) are issued by the International Accounting Standards Board (IASB), a committee of 14 memberswho are from nine different countries work together to develop global accounting standards. At present, there are two sets of accounting standards that Generally Accepted Accounting Principles (GAAP), USA based and International Financial Reporting Standards (IFRS) have been issued by International Accounting Standards Board (IASB), London based. Generally Accepted Accounting Principles (GAAP) arevery different in nature but based on a few basic principles of GAAP rules.India also set up its own accounting standard namely Indian Accounting Standard (Ind-AS) from April, 2015to fulfilling all the requirement of IFRS in the country for matching the gap between IFRS and Indian accounting standards. This study is based on secondary data tries to investigate the benefits \& challenges of IFRS application from which India can draw a lesson towards implementation of IFRS, converged Ind-AS and recommends must do reflections for a successful takeover. It highlights main benefits of IFRS adoption to include; enhanced transparency \& comparability; improved quality of accounting information; reduced cost of processing information; augmented cross border investments \& acquisitions; substantiated economic growth and financial stability. It recommends to the countriesvarious prerequisites are necessary for effective application and conformance with IFRS to store full benefits. This paper also presents a literature about the benefits of adoption of IFRS and related implementation challenges, reflects for successful application of converged Indian Accounting Standards (Ind-AS). Finally the paper presents the significance of IFRS and challenges for implementation.
\end{abstract}

Keywords: IFRS, GAAP, IASB, Ind-AS, ASB

\section{Conceptual Framework}

International Financial Accounting Standards (IFRS) are the Standards, Interpretationsand Framework for the Preparation and Presentation ofFinancial statements adopted by the International Accounting StandardsBoard (IASB). International Accounting Standards were issued in the year 1973 and year 2001 by the board ofthe Internal Accounting Standards Committee (IASC). On April 1 ${ }^{\text {st }}, 2001$ the new IASB took over the responsibility of setting International AccountingStandards from IASC. This body has continued to developstandards known as IFRS.In this journey India is an emerging economy in the world, it wants to integrate its financial reporting with rest of the economies of the world so that investors from worldwide will be able to understand the financial statements and the positions of the companies. The need to communicationaround the globe has been increased with the increase in global trade and international markets. Global adoption of prime IFRS are considerably observed in whole world so India can't be exempted in thismove. For fulfilling the norms of IFRS convergence process was started back in 2004 [32] and achieved in August 2006 on the formation of the IFRS task force [29]. India followed convergencemethod of IFRS for implementation itis a process whereby domesticaccounting standards are gradually aligned with IFRS with consequent intent to full compliance. 
In this reference a full convergence has been achieved through differences between IFRS and domestic accounting standards of the countries that may fulfill the requirements as per IFRS.

Structure of IFRS: International Financial Reporting
Standards are principle based set of standards that establish broad rules and also dictate specific treatments; there are Fifteen (15) IFRS, Twenty eight (28) IAS, Seventeen (17) IFRIC and Ten (10) SICs, which have following categories:

Table 1. International Financial Reporting Standards with introduced year.

\begin{tabular}{|c|c|c|}
\hline Reporting Standards & Issued Year & No. of Standards \\
\hline International Financial Reporting Standards (IFRS) & Issued after 2001 & 15 \\
\hline International Accounting Standards (IAS) & Issued before 2001 & 28 \\
\hline Interpretations Originated from the International Financial Reporting Interpretations Committee (IFRIC) & Issued after 2001 & 17 \\
\hline Standing Interpretations Committee (SIC) & Issued before 2001 & 10 \\
\hline
\end{tabular}

It is however; stronglyencouraged that countries ultimate goal for convergence plan should be full adoption of IFRS [33] and probably with allowance to minimal exceptional cases pertinent to social and economic settings of a respective country. Other countrieswhich had have used convergence path, include China [3]; Denmark \& Singapore [33] Australia, Canada \& South Africa for unlisted Companies [6].The need for Local rules convergence with IFRS in India is partly a function of recent opening of its economy which islinked with strong economic growth, rising of foreign exchange reserve and global recognition of its technological competencies [33]. This has notably necessitated a move towards making Indian accounting systemglobally acceptable (Bhattacharya, 2012) which is necessary in enabling Indian companies to compete inglobal markets. This is observed integrated global economies, cross border mergers \& acquisitions and interdependencies of capital markets [9] which can never be ignored. Keeping this in mind, AccountingStandard Board (ASB) of Institute of Chartered Accountants of India (ICAI) decided to form an IFRS task force in August 2006. Moreover, based on the recommendation of this task force, the Council of ICAI in $269^{\text {th }}$ meeting decided to fully convergewith IFRS from the accounting periods commencing from $1^{\text {st }}$ April 2011 [10] and expected to end by April, 2014 [31]. Notwithstanding, it didn'tmean that every company would follow IFRS in India [22] they were firstly applicable to publicly accountableand large sized entities. In the process of convergence or adoption of roadmap of(Indian Accounting Standards (Ind-AS) was diversified in threephases, first phase on April $1^{\text {st }}, 2011$, second phase on April1 $1^{\text {st }}, 2013$ and final third phase on April 1 ${ }^{\text {st }}, 2014$
[18]. This was notified by the Ministry of Corporate Affairs (MCA) on January 22 $2^{\text {nd }}, 2011$. With the convergence progress of IFRS in India two sets were issued and applied [5], one is Indian Accounting Standards (Ind-AS) and second one is Indian GAAP both are mandatory under Sec (211C) of the Companies Act.

The adoption and subsequent application of IFRS arecounted as result in the landscape change for financial reporting in India as they personate the most commonly accepted global accounting framework [31]. The Ind-AS were initially set to be obligatory for listed, public interest entities and large sized organizations with effect from April $1^{\text {st }}, 2011$. The move proved futile [30] and observed to be due to failure to meet the timeframe [31] and unresolved tax issues [14] among others. However, the failure Indian Government emphasized and proved its unrepentant commitment towards convergence, thus another adoption dates has recently been announced in February 16 ${ }^{\text {th }}, 2015$. Finance Ministerannounced the budget in 2014 than he urged an urgent need to adopt the current Indian Accounting standards converged with IFRS [8] in this the revised timeline for adoption of Ind-AS largely converged but not identical to IFRS [7] have been notified. The adoption of revised Ind- AS expects to start in April $1^{\text {st }}, 2015$ and at the end of April $1^{\text {st }}, 2017$ [31]. Hereto, according to ICAI to date 39 Ind-AS converged to IFRS are in issue and uploaded on MCA website [31], till the present we have converged fifteen Ind-AS as per IFRS rest accounting system is running as accordance IAS (Table2). With the global IFRS acceptance and consequent application it is therefore possible to collect evidence about the extent to which the IFRS benefits the capital markets.

Table 2. List of Ind AS and corresponding IFRS.

\begin{tabular}{lll}
\hline (Ind-AS) & Title & Corresponding IFRS \\
\hline (Ind AS) 101 & First time adoption of Indian Accounting Standards & IFRS 1 \\
(Ind AS) 102 & Share -based payment & IFRS 2 \\
(Ind AS) 103 & Business Combinations & IFRS 3 \\
(Ind AS) 104 & Insurance contracts & IFRS 4 \\
(Ind AS) 105 & Non-current Assets held for sale and Discontinued Operations & IFRS 5 \\
(Ind AS) 106 & Exploration for and Evaluation of Mineral Resources & IFRS 6 \\
(Ind AS) 107 & Financial Instruments: Disclosures & IFRS 7 \\
(Ind AS) 108 & Operating Segments & IFRS 8 \\
(Ind AS) 109 & Financial Instruments & IFRS 9 \\
(Ind AS) 110 & Consolidated Financial Statement & IFRS 10 \\
\hline
\end{tabular}




\begin{tabular}{lll}
\hline (Ind-AS) & Title & Corresponding IFRS \\
\hline (Ind AS) 111 & Joint Arrangements & IFRS 11 \\
(Ind AS) 112 & Disclosure of Interests in Other Entities & IFRS 12 \\
(Ind AS) 113 & Fair Value Measurement & IFRS 13 \\
(Ind AS) 114 & Regulatory Deferral Accounts & IFRS 14 \\
(Ind AS) 115 & Revenue from Contracts with Customers & IFRS 15 \\
\hline
\end{tabular}

Source: Government of India, MCA Press Information Bureau.

IFRS in Indian context at present:Accounting Standards Board (ASB) formulates and issues accounting standards in India which are more or less in line with IFRS except few legal, regulatory and economic environment. Council of the Institute of Chartered Accountants of India (ICAI) opined in May 2006 that adopting IFRS was considered and supported by the ASB. IFRS task force was set up to provide a road map for convergence and it decided to converge with IFRS from the accounting period commencing on or after 1 April 2011. In the country, Ministry of Corporate Affairs (MCA) of the Central Government has persuaded the process of convergence of Indian Accounting Standards with IFRS after a wide range of consultative process with all the stakeholders in pursuance of G-20 commitment and as result Thirty five Indian Accounting Standards converged with International Financial Reporting Standards Conversion is much more than a technical accounting issue. Indian AS (the converged IFRS standards) in India may significantly affect a company's dayto-day operations and may even impact the reported profitability of the business itself. On $2^{\text {nd }}$ January 2015, the Press Information Bureau, Government of India, Ministry of Corporate Affairs (MCA) issued a note outlining the various phases in which Indian Accounting Standards converged with IFRS (Ind-AS) which is implemented in India for Companies.Mostly Indian Companiesare reporting their financial statements as per Indian Accounting Standards prepared by Institute of ICAI. These Standards are quite similar to IFRS, till date, ICAI has issued 39 Accounting Standards (Ind-AS) covering many areas. The companies which have adopted IFRS and smoothly working on patterns are Infosys Ltd, Wipro Ltd, Dr. Reddys Lab Ltd, BhartiAirtel Ltd, Sterlite Industries Ltd, Tata Motors Ltd, Seimens Ltd, Tata Consultancy Ltd, Great Eastern Energy Corporation Ltd and Noida [18].

Indian Accounting system throughout the last few decades of the $20^{\text {th }}$ century there has been significant economic development in India. We look at India's accounting system as it is an important developing country with the second largest population after China and the fourth largest in terms of purchasing power. Although the countries accounting system is largely based on the Companies Act-1956, there was a paradigm shift in government policies and attitudes towards regulation since the 1991 economic crisis. Since economic reforms of 1991, towards a market based economy, it has become one of the fastest growing economies in the world. TheAccounting system of India and regulations are based on social system model which is defined as systems formulated and implemented by social entities with the objective of fulfilling social functions [32]. It is expected that factors such as colonization, imperialism, war, and economic concerns are the factors which play animportant role in hortative change [24]. Using the social system model in the political, economic and cultural aspects of a society bring about the development and changes in its Accounting systems and regulations in India.

\section{Review of Literature}

The implementation of IFRS removes the accounting confusion from the investor's mind because of similarity in accounting process [16]. The convergence of IFRS with Indian Standards was beneficial to the country for similarity in accounting system [22]. The use IFRS to various countries similarly seen to Indian benefits [30]. The IFRS implementation significantly reflect more respondents rated as difficult, considerable, or serious, rather than as easy or little, items making up General Issues with IFRS and Accounting Issues [25]. Single set of high quality standards would be in public interest and provide a uniform language for financial reporting will have a positive impact overall [29]. Small and midsized industry will face challenge in terms of scarcity of expertise. Costs will also be incurred for upgrading the IT system. In reference of numerous challenges, adoption of IFRS in India has changed the contents of financial statements [17]. The firms and companies will be easy in accounting and financial statements by using IFRS if their stakeholders are conversant with such new standards [26].

Objectives: We have worked with the following objectives in present research paper:

1. To study of IFRS and Indian Accounting Standard (IndAS).

2. To understand the procedure for issue of IFRSand Indian Accounting Standard.

3. To evaluate the challenges and benefits while adaption of IFRS in India.

\section{Research Methodology}

The present research work is the combinations of descriptive and exploratory nature where the challenges, remedies and benefits will be explore to follow the IFRS procedures. The research work also provides an insight on the future prospects by following the convergence process. The used data and information are based on secondarysources which arecollected through various websites and journals, as well as published books.

Scope of the study: The adoption of IFRS will increase the international business which leads to the economic growth 
and development of a country as well as increase the foreign investment inflow into the country. The IFRS would increase the comparability between the Financial Statements of various companies across the world. The industry also would be able to enhance the capital from the foreign markets at lower cost if it may create confidence in the minds of investors that our Financial Statements meet with the rest of the world Accounting Standards. The adaptation of Indian accounting standards with the IFRS would reduce different accounting requirements prevailing in various countries thereby enabling the enterprises to reduce the cost of compliances.

Need of the study: The impact of globalization and harmonization is currently being witnessed around the world, so the need to adoption of IFRS is becoming increasingly evident; certain jurisdictions have been quicker adoption of International Financial Reporting Standards, as well as highlighting the need for the adoption of IFRS.

IFRS Adoption Procedure in India: In the year 1949, Indian government to streamline accounting practices in the country established Institute of Chartered Accountants of India by passing ICAI Act, 1949. Accounting Standard Board was constituted by ICAI in the year 1977 with a view to harmonize the diverse accounting policies and practices in India. The other objectives of the board are; to consider and designate the new domain for Accounting Standards, formulation of Accounting Standards, review the existing Accounting Standards and revise as per need, adaptation of Indian accounting standards with IFRS.In the year 2006, a task force was set up by ICAI with the objectives to lay down a road map for convergence of IFRS in India on the basis of recommendationsand public opinions on IFRS adoption which were made by the task force, the adoption of IFRS was made in three phases with the three step process by the accounting professionals in India as following:

1. Phase I: The companies which were belonging to category of NIFTY 50, SENSEX 30, whose securities were listed on stock exchanges outside from India, which may be listed or not, having total net worth greater than 1,000 crores will convert their opening balance sheets if the their financial year starts on or after April $1^{\text {st }}, 2011$ in as per the prescribed accounting standards that are convergent with IFRS.

2. Phase II: The companies having total net worth more than 500 crores but less than 1,000 crores, whether listed or not, will be converged their opening balance sheet as at April $1^{\text {st }}, 2013$ if their financial year begins on or after April 1 $1^{\text {st }}, 2013$ as per the notified accounting standards which are in convergent with IFRS.

3. Phase III: The listed companieshaving total net worth of 500 crores or less will have to convert their opening balance sheet as at April $1^{\text {st }}, 2014$ if their financial year begins on or after April $1^{\text {st }}, 2014$ whichever is later, as per the notified accounting standards that are in convergent with IFRS.

4. Assessment the Impact of IFRS: In first step, the firms have to assessthe impact of IFRS adoption on
Accounting and Reporting Issues in the firm'sbusiness. The firm will then identify the key conversion dates and accordingly IFRS training plan will be laid down. The firm will have to identify the key Financial Reporting Standards after the training plan confirmation that will apply to the firm and also remove the variation among current accounting standards being followed by the firm and IFRS. The firm will have to identify the loopholes in the existing system.

5. Preparations for IFRS Implementation: This second step will perform the activities which are needed for IFRS implementation process as documentation of IFRS Accounting Manual. The firm will improve the internal reporting systems and processes for making the convergence process fair, various exemptions are given in IFRS-1 which may be identified and applied for ensuring that the IFRS are applied properly and homologically, control systems have been designed and put in proper place.

6. Implementation: Third and lastly, the first activity must be to prepare an opening Balance Sheet at the date of transition to IFRS.A smooth understanding of the impact of the convergence from Indian Accounting Standards to IFRS is to be maintained which will follow the whole exercise of IFRS. First time application of IFRSneeds to various type of training althoughvarious difficulties may also be faced. To ascertain a properconvergence from Indian Accounting Standards to IFRS, regular training to staff and addressing all the problems that would be faced while performing the implementation is also needed.

Challenges for IFRS implementation in India: The challenges in application of IFRS in India are as under:

Fair Value Accounting: The use of fair value accounting may bring instability to the financial statements it is very stiff to arrive at the fair value and valuation experts also feel stiff to shift from historic method to fair value method. Besides, adjustments to fair value results in gains or losses which are shown in the income statements. Though this may be included in calculating distributable profit is also questionable issue. The fair value financial reporting under IFRS got scuffled in the present economic fluctuations in global financial markets and institutions. On the basis of fair value accounting banks and other organizations would be needed to acceptplace to place valuation of assets.

Training: One of the biggest issues in application of IFRS is that shortage of training programmes and courses on IFRS in India. IFRS foundation is offering Online IFRS program, diploma and certificate courses and also The ICAI has started IFRS Training programs interested parties. Although, there is a large gap between required professional and trained professionals available.

Taxation:Convergence of IFRS would affect the financial statements and consequently the tax liabilities, thus the taxation laws must be addressed the adjustment of tax liabilities germinated on convergence from Indian accounting standards to IFRS. A fully renewal in Tax 
Laws is the major challenge faced by the Indian accounting system which includessome major changes in Tax Laws in order to maintain tax authorities to recognize IFRS-Compliant accounting statements. It is extremely very important that the tax laws recognize IFRS complaint accounting system otherwise it would duplicity for the business entities.

Auditing:The audit firms in India are also affected because they have to audit at the fair value accounting according to the IFRS without proper guidance, currently these audit firms are performing the audit as per the cost concept accounting. IFRS are applied without proper audit guidance by the ICAI, so it may be unjustified to expect from the auditing authorities to discharge their duties as per the new Companies Act, 2013. This is also challenging forlocal audit firms, which hardly may have fewer availability of resources through affiliated firms. The audit firms would be needed to consider elements of their systems of quality control. Indian firms of auditing may encounter challenges in establishing policies \& procedures, hiring, training to personnel, to provide a reasonable assurance that the audit personnel would obtain knowledge to perform audits as per IFRS.

Other changes: International expertise shows that companies would be required proper preparation time to plan a fair transition and to communicate the effect of transition to all stakeholders. The regulators need for an active debate amongst companies, industrial associations and investors on the impact relating to the transition of IFRS.

Benefits to India in Adopting IFRS: The whole World's economies have been benefitted by adopting IFRS for financial and accounting reporting purposes. In review of literature previous studies have reflected various benefits of IFRS adoption, especially better financial and accounting information for all the related stakeholders in following manners:

1. Easy availability of Funds in Global Capital Markets:Since the last two decade, India has emerged as a strong economy on world's map. Indian firms are not only establishing the plants abroad but also acquiring other firms across the world so they need funds at small cost which is available in other Capital Markets like American, European and Japanese. The adoption of IFRS not only helps Indian Firms in accessing world Capital Markets for funds but also funds are available at cheaper cost.

2. Easier Global Comparability:The whole world Firms are using IFRS to reflecting their financial records so the adoption of IFRS by Indian firms, the comparison of two becomes easier. Various stakeholderslike investors also find it easy to compare the financial records following the similar reporting process. Majority of Indian companies are accessing European capital markets, preparing and presentingthe financial records on the basis of IFRS which helps to the firms in easy accessibility of funds from world's capital markets.

3. Easy Listing across the Border:Indian firms are requiring funds for expansions to their business which is not limited to the boundaries of the country because theseFirms are acquiring firms abroad also and getting listed in European and American Capital Markets through raising funds. One of the major requirement of getting listed on European Markets is Accounts must be meet as per IFRS requirements so few Indian firms which have been raised the funds from the European Capital Markets, have started preparing the Financial records as per IFRS.

4. Better record Financial Reporting: In application and adoption of IFRS is expected to result will be better of financial reporting due to similarity of Accounting Principles. The IFRS follows a concept of smooth value which may help to the Indian firms to present their true worth of Assets. Though a single body (IASB, London) is consistently preparing IFRS, which are reliable and easy to adopt for better quality of financial statements.

5. Elimination of Multiple Reporting: Large Business and corporate Houses of the countrylike TATA, BIRLA, AMBANI and ADANI have companies registered in India as well asbroadly in European and American capital markets. These companies registered in India and prepare financial statements as per Indian Accounting Standards in other ways these firms registered in other countries so they have to maintain their financial records as per respective country reporting standards. But adoption of IFRS ensures to solve this reporting standards difficulty of multiple financial reporting standards by these companiesso they now can follow a single set of Financial Reporting as IFRS.

\section{Conclusion and Implications of the Study}

The present study is limited to desktop and library review to investigate the challenges and remedies as benefits of IFRS adoption by which India may draw a lesson towards application of IFRS converged to Ind-AS. The paper reflects notable IFRS benefits to improve quality of financial reporting; elimination of multiple reporting standards and ensuring easy to making decision; easy listing across the border and reduce cost of capital. Further, the paper reports that the IFRS are not free from the challenges, as inclusive of complicated nature; insufficient qualified personnel; fair value intent of standards which undergo from availability of liquid data; and lack of coordination between financial reporting regulators. Finally the paper concludes that the benefits for IFRS convergence are real but not automatic in other hand challenges in the way of adoption and convergence can't be ignored thus the recommendation to all the stakeholders that they must participate activelyfor a successful move. 


\section{References}

[1] Barth, M. E., Wayne R. L., Lang M. H., (2008). International Accounting Standards and Accounting Quality. Journal of Accounting Research. Vol. 46, 467-498.

[2] Beria, Kumar, S., (2010). IFRS in real estate- A technical area mare than just accounting and reporting. The Chartered Accountant Journal. Vol. 58 (12), pp 1963-1973.

[3] Bhatacharjee, S and Islam, Z. M. (2009). Problems of Adoption and Application of IFRS in Bangladesh. International Journal of Business and management. Vol. 4 (12).

[4] Bhattacharya, Joydes (2012). Revised schedule VI- A scientific approach towards preparation of financial statements? The Chartered Accountant Journal. Vol. 61 (3), pp 444-452.

[5] Callao, S. \& Lainez, Jose, A. (2000). The effects of Accounting Diversity on international financial Analysis: Empirical Evidence. The International Journal of Accounting. Vol. 35 (1), pp.65-88.

[6] Chamisa E. E. (2000). The relevance and observance of IASC standards in developing countries and the particular case of Zimbabwe. The International Journal of Accounting. Vol. 35 (2), 267-286.

[7] D'souza, \& Dolphy, (2007). IFRS the way forward. The Chartered Accountant Journal. Vol. 55 (11), pp 1692-1695.

[8] D'souza, Dolphy (2014): 'Managing the pitfalls for Ind-AS adoption in India'. Available on: http://articles.economictimes.indiatimes.com/20140829/news/53362679_1_indian-gaap-indian-mnc-mca.

[9] Dancey, K (2012): 'The future of accounting -A Canadian perspective', The Chartered Accountant Journal, Vol. 61 (1), pp 77-80.

[10] Daske, H., Hail, L., Leuz, C. and Verdi, R (2008) 'Mandatory IFRS reporting around the world: early evidence on the economic consequences', Journal of Accounting Research, 46 (5), pp.1085-1142.

[11] Deloitte (2011): 'Ind AS consideration for Board and Audit Committees', Available

http://www.iasplus.com/en/publications/india/ind-asconsiderations-for-boards-and-audit-committees.

[12] Deloitte (2015). Indian GAAP, IFRS and Ind AS: A Comparison',

Available onhttp://www.iasplus.com/en/publications/india/indian-gaapifrs-and-ind-as-a-comparison/view.

[13] Deloitte (2015). Preface to International Financial Reporting Standards. Available
http://www.iasplus.com/en/standards/other/preface.

[14] Ding Yuan, Hope Ole-Kristian, Jeanjean, Thomas and StolowyHeme, (2007). Differences between Domestic Accounting Standards and IAS: measurement, Determinants and Implications. Journal of Accounting and Public Policy. Vol. 26, 1-38.
[15] Edogbanya, A. \& Kamardin, H. (2014). Adoption of IFRSs in Nigeria: Concepts and Issues. Journal of Advanced Management Science. Vol. 2 (1).

[16] Espinosa, German L, and Biscarri, Javier G, (2007). The influence of differences in accounting standards on empirical pricing models: An empirical implication of Fama-French model. Working Paper, No.13/07.

[17] Gupta A. (2012). Revenue recognition under IFRS. The Chartered accountant Journal. Vo. 60 (7), pp. 54-60.

[18] Herbert, Wilson E. Ene, Emeka, E. and TsegbaIoraver, N, (2014). Globalization of Financial Reporting: Obstacles of IFRSs Adoption in Nigeria. Asian Journal of Business and Management Science, Vol. 3 (12), 25-41.

[19] IASB (2015). IFRS application around the world, Jurisdiction profile: Tanzania. Available on, http//www.ifrs.org/use/aroundthe-world-/documents/jurisdictional-profiles/TZIFRSprofile.pdf.

[20] Kumar, R. (2015). Implementation of IFRS in India: Opportunities \& Challenges. International Journal of Business Management and Scientific Research. Vol.3, pp. 73-78.

[21] Muniraju M. \& Ganesh S. R. (2015). Convergence of International Financial Reporting Standards- Benefits, problems, Challenges for India. International journal of Informative \& futuristic Research. Vol. 01 (6), pp. 1548-1557.

[22] Preethi, S., Deepti, M., \& Rawat, D. (2015). Challenges and Prospects of IFRS in Indian Accounting Systems. International Journal of Core Engineering and Management, pp. 142-149.

[23] Tendeloo, B. \& Vanstraelen (2005). Earning Management under German GAAP versus IFRS. European Accounting Review. Vol. 14 (1), pp. 155-180.

[24] Veeramani, C. \& Mahendra, S. (2015). Overview-accelerating growth and development, challenges in short term and longterm. India Development Report, 2015, pp. 1-19, Indira Gandhi Institute of Development Research.

[25] World Bank Group, (2004). Report on the Observance of Standards and Codes (ROSC). India-Accounting and Auditing. pp. 1-34. http://www.worldbank.org/ifa/rosc_aa_ind.pdf.

[26] World Bank Group. (2005). Report on the Observance of Standards and Codes (ROSC) Tanzania Accounting and Auditing pp. 1-27. Available on http://www.worldbank.org/ifa/rosc_aa_tza_0405.pdf.

[27] World Bank Group. (2014). Global economic prospects, World Bank report, Vol. 9, June, 2014, Washington DC.

[28] www.ifrs.org.

[29] www.pwc.services.in.

[30] www.iasplus.com.

[31] www.mca.gov.

[32] www.icai.org.

[33] www.google.com. 


\section{Biography}

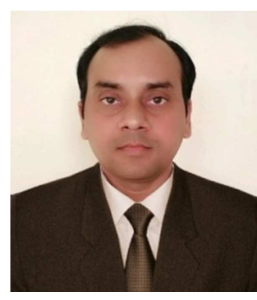

Ram Singh is Sr. Assistant Professor in School of Business \& Management, Quantum University, Roorkee, India. He has a PhD in Commerce from HNB Garhwal Central University Srinagar Uttarakhand India. He has published various research papers \& articles in different UGC listed \& Impact Factor Peer-reviewed journals. Besides this, he has also attended various FDPs, workshops, NPTEL Courses (IITR) conducted by renowned institutions \& organisations. He also presented papers in various national \& International seminars \& conferences and published more than ten articles / Chapter in proceedings of seminars \& Conferences.

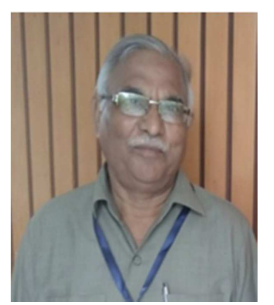

Santosh Kumar Srivastava is Professor, Ex. Head department of Commerce \& Ex.Dean, School of Commerce, HNB Garhwal Central University, Chauras Campus Tehri-Garhwal, Uttarakhand India having experience more than forty years in teaching as well as in research. He has decorated various designations in the university as Finance Officer, Dean, and Head etc. Prof. Srivastava supervised numerous research scholars in their PhD Thesis \& Dissertations in the area of account and finance. He has written many books, numerous research papers, articles for renowned journals and seminars proceedings. 